\title{
Heavy Metal Ion Pollution in Aqueous Solution: An Environmental Hazard
}

\author{
Rajib Biswas* \\ Department of Physics, Tezpur University, India
}

Submission: January 07, 2019; Published: January 17, 2019

*Corresponding author: Rajib Biswas, Applied Optics and Photonics Lab, Department of Physics, Tezpur University, Tezpur-784028, Assam, India

\section{Abstract}

In this concise communication, the growing pollution in aqueous solution caused by heavy metals is addressed. While highlighting the grave situation caused by them, the consequences are also briefed. Apart from this, the modalities and eventual solutions are also pointed out.

Keywords: Natural phenomena; Forest fire; Volcanic eruption; Landslides; Floods

\section{Opinion}

Aquatic systems are indispensable part of a balanced ecosystem which is abode to natural flora and fauna, biodiversity etc. If the natural ingredients, mainly the compositional elements are in less proportional amount; there is no harm done as there remains a total balance in the overall process of stakeholders [1-3]. However, since last two decades, there happens to be a serious factor which is posing as a large threat to the existing aquatic systems. There is a rise in concentration of heavy metal ion in aqueous solution which is gradually surging alarmingly [4-6].

When we talk about heavy metals; in general, the elements with an average molecular density of $5 \mathrm{~g} / \mathrm{cm}^{3}$ fall in this category $[5,6]$. However, not all of them qualify this criterion. Even then, the most hazardous heavy metal ions can be cited as lead, mercury, bismuth, arsenic, cadmium etc. Apart from these, iron, cobalt are also a member of this family. However, their toxicity is a little bit trivial as compared those already mentioned ions.

A close look at the root causes of heavy metal contamination reveal that they are basically caused by natural and manmade activities. However, the pollution level through natural phenomena such as forest fire, volcanic eruption, landslides, floods etc. are not to the extent as those caused by manmade activities. Potential sources of heavy metal ion pollution in aqueous solution through man-made activities include mining, tailings, industrial wastes, agricultural run-off, occupational exposure, paints etc and so many. They enter the bio-system as end products which get on accumulating during a long exposure.

World health organization, the premiere watchdog of all heavy metal ion pollution has set-up a permissible level for these ions in aqueous solution. If that is considered, most of these heavy metal ions possess a permissible level of $10 \mathrm{ppb}$. When the concentration of a certain heavy metal exceeds this limit; then it is no longer considered as a natural gradient; rather as a potential aquatic pollutant. As mentioned previously, the incessant growth of urbanization and industrialization has taken a serious toll in this issue. For instance, the intake of these heavy metals polluted water leads to serious health hazards such as water borne diseases. There happens to be respiratory problems, endocrine related disorders and so many. The mercurial pollution is another causing severe health concern over global community incurring causalities as well as endangering many species. Consequently, this is gradually leading to an imbalance in biodiversity.

Taking a serious note of these, there should be holistic approaches which can take care in the context of control; albeit not becoming a bottleneck in development. The stakeholders should look at the concern seriously. There should be strict monitoring of concentration of these ions with punitive measures for those who violate these norms. Regarding these, there must be development of cost-effective and rapid monitoring systems [4-6]. Alongside of it, there must be protocol of mandatory adherence to zero discharge in industrial sector which can act as a boon in the lessening of heavy metal ion induced pollution.

\section{Acknowledgement}

The author expresses sincere gratitude to the editors for allowing writing this concise communication.

\section{References}

1. Biswas R (2018) Challenging Factors Influencing Biodiversity, Biodiversity Online J 1(1): 1-2. 
2. Biswas S, Biswas R (2018) Water and Sustainability Issues: A global perspective. Journal of Aquaculture and Oceanography 2(3).

3. Biswas R (2018) Plastic Pollution: A Menace to Marine Biology. Ad Oceanogr \& Marine Biol 1(1): 1.

4. Baruah BS, Biswas R (2018) Localized surface plasmon resonancebased $\mathrm{U}$-shaped optical fiber probe for the detection of $\mathrm{Pb}^{2+}$ in aqueous medium. Sensors and Actuators B: Chemical.
5. Baruah BS, Biswas R (2018) An optical fiber based surface plasmon resonance technique for sensing of lead ions: A toxic water pollutant. Optical Fiber Technology 46: 152-156.

6. Baruah BS, Biswas R, Deb P (2019) A green colorimetric approach towards detection of arsenic (III): a pervasive environmental pollutant. Optics and Laser Technology 111: 825-829.

\section{Your next submission with Juniper Publishers will reach you the below assets}

- Quality Editorial service

- Swift Peer Review

- Reprints availability

- E-prints Service

- Manuscript Podcast for convenient understanding

- Global attainment for your research

- Manuscript accessibility in different formats ( Pdf, E-pub, Full Text, Audio)

- Unceasing customer service

Track the below URL for one-step submission https://juniperpublishers.com/online-submission.php 